Published by

Tadris Matematika

IAIN Syekh Nurjati Cirebon
EduMa: Mathematics Education Learning And Teaching

December 2020, Vol 9 No 2 Page $37-41$

https://syekhnurjati.ac.id/jurnal/index.php/eduma/index

\title{
EduMa
}

\section{The Impact of Online Learning through Students' Mathematical Habit of Mind}

\author{
Widyastuti $^{1^{*}}$, Santy Setiawati ${ }^{2}$, Mella Triana ${ }^{3}$ \\ 1,2,3 Mathematic Education, Department of Mathematisc and Science Education, Lampung University
}

*Corresponding author: Bandar Lampung, Lampung, 35132, Indonesia. e-mail addresses: widyastuti.1986@fkip.unila.ac.id

\begin{tabular}{|c|c|}
\hline a r t i c l e i n fo & a b s t r a c t \\
\hline How to cite this article: & THE IMPACT OF ONLINE LEARNING THROUGH \\
\hline $\begin{array}{l}\text { Widyastuti., Setiawati, S., \& Triana, M. (2020). } \\
\text { The Impact of Online Learning Through Students' } \\
\text { Mathematical Habit of Mind. Eduma: } \\
\text { Mathematics Education Learning And Teaching, } \\
9(2), 37 \text { - } 41 . \\
\text { doi:http://dx.doi.org/10.24235/eduma.v8i2.7156 }\end{array}$ & $\begin{array}{l}\text { STUDENTS MATHEMATICAL HABIT OF MIND. Online } \\
\text { learning became one of the most popular learning strategies during the pandemic of } \\
\text { Covid-19 in every level of education in Indonesia. This type of learning strategy } \\
\text { certainly has an impact on developing student's learning habit and also thinking } \\
\text { habit. The impact of the implementation of online learning need to be measured to } \\
\text { reveal the changes as the result of learning strategy which was adopted by the } \\
\text { educators. This impact needs to be studied from the mathematical habit of mind as } \\
\text { the point of view. The research method was survey research with population all } \\
\text { students of mathematics education study program in Lampung University. Simple }\end{array}$ \\
\hline Article history: & $\begin{array}{l}\text { random sampling was used as the sampling technique to obtain } 191 \text { students in even } \\
\text { semester of the 2019/2020 academic year as the sample. Data collected using }\end{array}$ \\
\hline Received: 09 25, 2020 & $\begin{array}{l}\text { questionnaire which measured variables self-perception mathematical habit of mind } \\
\text { and implementation of online learning. Data analyzed using simple linear regression }\end{array}$ \\
\hline Accepted: 11 17, 2020 & $\begin{array}{l}\text { on } \alpha=5 \% \text {. Based on data analysis, it can be concluded that the equation of the } \\
\text { regression that express the relationship of self-perception mathematical habit of }\end{array}$ \\
\hline Published: 12, 2020 & $\begin{array}{l}\text { mind }(\mathrm{Y}) \text { and implementasion of online learning }(\mathrm{X}) \text { is } \mathrm{Y}=0,246 \mathrm{X}+38,572 \text { which } \\
\text { indicates that there are significant low impact of implementation of online learning }\end{array}$ \\
\hline & on students self-perception mathematical habit of mind. \\
\hline
\end{tabular}

Copyright (C) 2020

EduMa: Mathematics Education Learning and Teaching under the Creative Commons Attribution 4.0 International License.

Key $\mathbf{y}$ ord s :

Online Learning; Mathematical Habit; Student's Mind; Pandemic 


\section{INTRODUCTION}

Online learning became one of the most popular learning strategies during the pandemic of Covid-19 in every level of education in Indonesia. Online learning utilizes internet in designing the learning process because of the level of flexibility and also the function that make learning easy to do anytime and anywhere (Irawan, Susanti, dan Triyanto, 2015). Internet as the huge library on earth also believe as all-round learning resource with the smart engine machine on it which provides abundant information to be accessed easily in an attractive appearance (Putranti, 2013). This type of learning strategy certainly has an impact on developing student's learning habit and also thinking habit. The impact of the implementation of online learning need to be measured to reveal the changes as the result of learning strategy which was adopted by the educators.

Oxford learner dictionary (2020) define impact as the powerful effect that something has on somebody/something. The impact of the implementation of online learning could be measured in many aspect of learning output such as mathematical habit of mind ( $\mathrm{MHoM})$ as the point of view. This is important to be measured because of the characteristic of habit of mind as one of crucial variable that indicate students thinking behavior in solving problems through their own thoughts by utilizing the prominent information source effectively and engaging optimal efforts by improving their own evaluation standards. Ritchart \& Tishman (Waryadi, Kadir, Rahayu, 2019) mentioned that MHoM is needs as thinking transition in studying higherlevel material. Moreover, Setiawati (2014) give evidence about the association between logical and creative thinking skills with students' MHoM behavior.

\section{METHODS}

The population in this research is all students of mathematic education study program in Lampung University. Simple random sampling was used as the sampling technique to obtain 191 students in even semester of the 2019/2020 academic year as the sample. This quantitative research described the relationship of self-perception $\mathrm{MHoM}$ (Y) and implementation of online learning (X).

Data collected using questionnaire which measured variables self-perception mathematical habit of mind and implementation of online learning. Using one shoot case study to identify the quality of research intruments, the research intrument has 24 items to measure selfperception MHoM and 30 items to measure the variable of implementation of online learning that has reliability coeficient in high category.

After data collected, data were converted using method of succesive interval to gain interval scale, then analyzed using simple linear regression on $a=5 \%$. The convertion process into intervale scales is needed to fulfil the prerequisit assumtion of linear regresion test. Another assumption for simple linear regression is normality assumption for the residual. The residual data in this research has a normal distribution. This is based on the P-P Plotting on the residual values as illustrtated in Figure 1. 


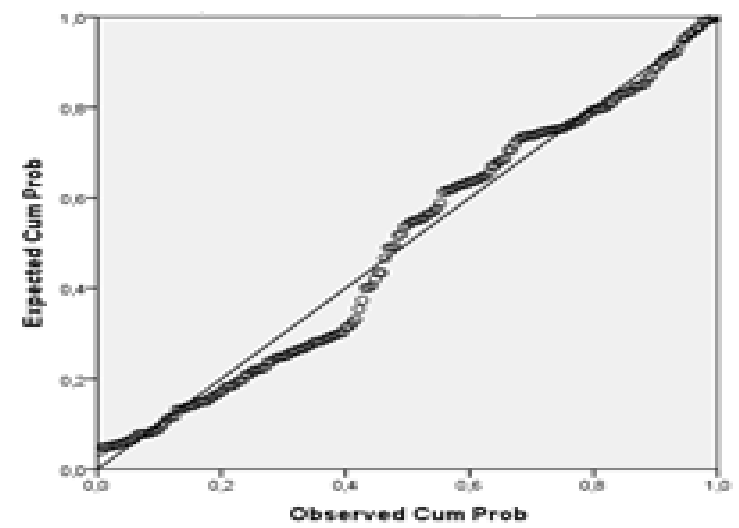

Figure 1 Normal P-P Plot of Regression Standardized Residual

Based on Figured 1, the residual values plotting along the linear line which indicates that the distribution of the residual fit the normal distribution.

\section{RESULT AND DISCUSSION}

After data about self-perception MHoM and implementation of online learning were collected, the ordinal data were converted into interval scale using method of successive interval. Then data analyzed descriptively using the interval scale and the result showed in Table 1.

Tabel 1

Descriptive Statistics

\begin{tabular}{lcccccc}
\hline & N & SMI & $\boldsymbol{x}_{\text {Min }}$ & $\boldsymbol{x}_{\text {Max }}$ & $\overline{\boldsymbol{x}}$ & $\mathbf{s}$ \\
\hline SP & 191 & 81,48 & 41,84 & 64,99 & 50,09 & 4,35 \\
IP & 191 & 72,93 & 41,05 & 58,99 & 46,71 & 3,48 \\
\hline
\end{tabular}

Annotation:

$\mathrm{SP}=$ variable of self-perception of $\mathrm{MHoM}$

IP = variable of implementation of online learning

$\mathrm{N}=$ number of responds

$\mathrm{SMI}=$ maximum ideal score

$x_{\text {Min }}=$ minimum score

$x_{\text {Max }}=$ maximum score

$\bar{x}=$ average score

$\mathrm{s}=$ standard deviation

Based on Table 1, if the percentage of the average score for data of variables selfperception $\mathrm{MHoM}$ and implementation of online learning were counted, respectively gain $61,48 \%$ and $64,05 \%$ which is in high category based on Riduwan (2008). The percentage for the minimum score of both variables respectively are $51,35 \%$ and $56,29 \%$ which is in moderate category. It portrays good quality of student's selfperception of MHoM and implementation of online learning. Analysis results that illustrate the relationship between both variables as shown in Table 2.

Table 2

\begin{tabular}{ccccccc}
\multicolumn{6}{c}{ Output of Determination Coefficient } \\
\hline $\mathbf{R}$ & $\mathbf{R}^{\mathbf{2}}$ & $\mathbf{F}$ & $\mathbf{d f 1}$ & $\mathbf{d f 2}$ & \multicolumn{1}{c}{ Sig. F } \\
& & & & & \\
\hline $0.197^{\text {a }}$ & 0.039 & 7.621 & 1 & 189 & 0.006
\end{tabular}

Based on Table 2, the $\mathrm{R}^{2}$ value $=0,039$ which indicates only $3.9 \%$ of the variance of student's self-perception MHoM could be explained by the implementation of online learning. The Sig. $F=0.006<a=$ 0.05 give strong conclusion that the $r$ value is significant. The regression equation which describe the relationship between variable $\mathrm{X}$ and variable $\mathrm{Y}$ is presented in Table 3.

Table 3

Output Test of Simple Linear Regression

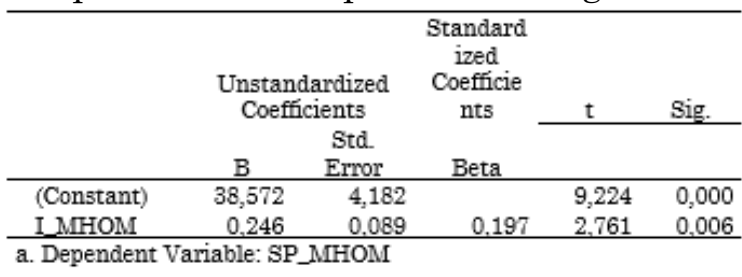

Based on Table 3, the model of the regression which point the relationship between $\mathrm{X}$ and $\mathrm{Y}$ is $\mathrm{Y}=0,246 \mathrm{X}+38,572$. The significance test for the model shown in Table 4.

Table 4

Output of Significant Test of Regression

\begin{tabular}{|c|c|c|c|c|c|}
\hline & $\begin{array}{l}\text { Sum of } \\
\text { Squares }\end{array}$ & $\mathrm{df}$ & $\begin{array}{l}\text { Mean } \\
\text { Square }\end{array}$ & $\mathrm{F}$ & Sig. \\
\hline Regression & 139.473 & 1 & 139.473 & 7.621 & $0.006^{b}$ \\
\hline Residual & 3458.762 & 189 & 18.300 & & \\
\hline Total & 3598.235 & 190 & & & \\
\hline
\end{tabular}

b. Predictors: (Constant), IPS_MHOM

Based on Table 4, the sig. value $=0.006<$ $a=0.05$ which means, in 5\% level of significance regression model $\mathrm{Y}=0,246 \mathrm{X}$ $+38,572$ is a significant simple linear regression equation. 
The equation $\mathrm{Y}=0,246 \mathrm{X}+38,572$ illustrate the positive relationship of student's self-perception MHoM and implementation of online learning. This significance relationship tells that every one unit increase of the quality of implementation of online learning will affect the increase of 0,246 point of the student's self-perception of MHoM. Thus, mean that the implementation of online learning has a positive impact on student's perception of their MHoM which is still in low category of impact. It might be because of student's self-perception of MHoM already in high category so the students can quickly adapt to the situation of online learning and of course the interval of changes tend to be narrower if compared with the students in low category of MHoM.

This high category of self-perception oh MHoM could represent strong disposition of intelligent behavior (Costa\&Kallick, 2008). Student's with high quality of MHOM will able to encounter a variety of mathematical problems independently with full confidence that vary from simple to the very complex one. In another words, habit of thinking did not automatically develop through learning but must be designed specifically (Rustaman, 2008).

Irawan, Susanti, dan Triyanto (2015) reported that the use of internet in learning is still partial, wider the study gap and cause unequal distribution of the quality of learning between each student. For higher education, online learning mostly assumed as a repository of teaching materials for both teachers and students (Wicaksono, 2012). In fact, the concept of learning in higher education is more andragogy which means the online learning should be designed to be more participatory. Schmidt, Dickerson \& Kisling emphasize that students in higher education level, could be grouped as adult learner which likely to have extrinsic motivation to learn what they want to learn and they know better what they want to learn (Wicaksono, 2012).

\section{CONCLUSION AND IMPLICATION}

The implementation of online learning (X) gave a low impact on student's mathematical habits of mind (Y) which follow the equation $\mathrm{Y}=0,246 \mathrm{X}+38,572$. That means the impact which indicates that there are significant low impact of implementation of online learning on students self-perception mathematical habit of mind.

\section{REFERENCES}

Costa, A. L., \& Kallick, B. (2000). Describing 16 Habits of Mind. Habits of Mind: A Development Series. Alexandria, VA.

Costa, A. L., \& Kallick, B. (2009). Habits of mind across the curriculum: Practical and creative strategies for teachers. ASCD. Retrived from https://books.google.com/books?hl=en $\& l r=\& i d=r Q V R B A A A Q B A J \& o i=$ fnd $\& p g=$ PR9\&dq $=$ Habits + of + mind + acro ss+the+curriculum: + practical + and $+\mathrm{c}$ reative+strategies + for+teachers. + In + Association+for+Supervision+and + Curriculum+Development\&ots $=\mathrm{GoH}$ bs8VGeg\&sig=fInloRbtagy8DeZATr $\underline{\mathrm{h} 63 \mathrm{IEvVrw}}$

Irawan, Y., Susanti, N., \& Triyanto, W. A. (2015). Analisa dan perancangan sistem pembelajaran online (elearning) pada smk mambaul falah kudus. Simetris: Jurnal Teknik Mesin, Elektro dan Ilmu Komputer, 
6(2), 345-352. Retrived from https://jurnal.umk.ac.id/index.php/si $\underline{\text { met/article/view/471 }}$

Oxford learner dictionary (2020). Oxford learner dictionary. Retrieved from www.oxfordlearnersdictionaries.com

Putranti, N. (2016). Cara Membuat Media Pembelajaran Online Menggunakan Edmodo. Jurnal Pendidikan Informatika dan Sains, 2(2), 139-147. Retrived from http://journal.ikippgriptk.ac.id/index .php/saintek/article/view/224

Rustaman, N. Y. (2008). Habits of Mind in Learning Science and its Assessment. Bandung: Indonesia University of Education. Retrived from

https://www.researchgate.net/profile/ Nuryani_Rustaman/publication/266 506476_HABITS_OF_MIND_IN_LE ARNING SCIENCE AND ITS ASS ESSMENT/links/5adca140aca272fda f861b92/HABITS-OF-MIND-INLEARNING-SCIENCE-AND-ITS-

\section{$\underline{\text { ASSESSMENT.pdf }}$}

Setiawati, E. (2014). Mengembangkan Kemampuan Berpikir Logis, kreatif, dan Habits of Mind Matematis Melalui Pembelajaran Berbasis Masalah: Eksperimen terhadap Siswa Madrasah Aliyah (Doctoral dissertation, Universitas Pendidikan Indonesia). Retrieved from http://repository.upi.edu/6583/.

Waryadi, W., Kadir, K., \& Rahayu, W. (2019). Effect of Bamboo Dance Learning Model and Early Ability Against Habit of Mind Mathematical Students. Journal of Development Research, 3(2), 52-59. Retrived from http://journal.unublitar.ac.id/jdr/inde x.php/jdr/article/view/76

Wicaksono, S. R. (2012). Kajian Pembelajaran Online Berbasis Wiki Di Lingkup Perguruan Tinggi. Journal of Education and Learning, 6(1), 51-58. 